\title{
Integrated Value Chain Development: Evidence from Bangladesh
}

\author{
Rob Kuijpers \\ rob.kuijpers@kuleuven.be \\ LICOS Centre for Institutions and Economic Performance \\ KU Leuven
}

Version: May 2020

\begin{abstract}
Agricultural productivity and farmer welfare in developing countries is constrained by a multi tude of market imperfections. Value chain development (VCD) is receiving much attention as a market-based policy instrument that can potentially address multiple of these constraints simultaneously. This paper provides a conceptualization of VCD and discusses how VCD can be used as a policy instrument. As an illustration, the paper describes the VCD project "SAFAL", which uses an integrated approach to directly intervene in the aquaculture, horticulture, and dairy value chains in South-West Bangladesh. The strategy is to first identify a demand downstream in the value chain and then to identify and reduce the constraints experienced by value chain actors upstream to meet this demand. Using a matched difference-in-difference methodology, this paper estimates farm household participation in SAFAL increases farm income and shortens the hungry season.
\end{abstract}

Key words: value chain development, market access, impact evaluation, aquaculture, smallholder, food security.

JEL classification: Q12, Q13, O13, O19, O22.

\footnotetext{
Acknowledgements: I am grateful to a large team of researchers with whom I collaborated to conduct the impact evaluation of SAFAL: Jan-Joost Kessler, Philip de Jong, Ferdous Jahan, Maartje Gielen, Fahim Chowdury, Omar Faruque Siddiki, and Ferko Bodnár. The data collection conducted in Bangladesh was part of a country case study by Aidenvironment, APE, BRAC/DRI and IHE for the IOB Evaluation of the Dutch food security policy 2012-2016, and was funded by the Dutch Ministry of Foreign Affairs. I also want to thank the staff at Solidarid and at the Netherlands embassy, in particular: Selim Reza Hasan, Indu Bhushan Roy, Jan-Willem Nibbering, and Laurent Umans. I am thankful for the valuable feedback I received on earlier versions of this paper from Jo Swinnen, Ruerd Ruben, Rob Vos, Joachim de Weerdt, Joachim Vandercasteelen, and the participants at the GlobalFood Conference in Gottingen. Finally, I acknowledge research funding from the KU Leuven Methusalem Fund. All remaining errors are mine.
} 


\section{Introduction}

Agricultural productivity and farmer welfare in developing countries is constrained by a multitude of market imperfections. Farmers incur high costs and face uncertainty when buying improved plant and animal varieties, farm chemicals, equipment, finance, or information services (e.g., Bold et al. 2017; Croppenstedt, Demeke, and Meschi 2003; Shiferaw et al. 2015) and when selling their produce, particularly if buyers require them to comply with stringent standards regarding quality and food safety (e.g., Maertens, Minten, and Swinnen 2012; Pingali, Khwaja, and Meijer 2005; Reardon et al. 2009; Svensson and Yanagizawa 2009). These market constraints are often mutually reinforcing. Low access to one farm input can reduce the incentive to adopt other farm inputs as a result of complementarities (e.g., see Christiaensen and Vandercasteelen 2019). In turn, low access to farm inputs can reduce access to output markets by constraining productivity and by hindering compliance with public and private standards (Barrett 2008; Kuijpers and Swinnen 2016).

Value chain development (VCD) is receiving much attention as a market-based policy instrument that can potentially address the multiple binding market constraints on agricultural productivity in an integrated way (Christiaensen and Vandercasteelen 2019; Fuglie et al. 2019; Dejanvry and Sadoulet 2020). Despite this attention, there is limited evidence on the effectiveness of VCD as an integrated policy solution (Barrett et al. 2019; Christiaensen and Vandercasteelen 2019; Deveaux et al. 2016; Fuglie et al. 2019). Meanwhile, governments, donors, and international organizations are investing large sums of public funds in VCD. ${ }^{1}$

\footnotetext{
${ }^{1}$ Between 2012 and 2016, the Netherlands, for example, financed more than fifty public-led agri-food VCD programs in developing countries for a total value of EUR 417 million (IOB 2018). Kolavalli et al. (2015) report that about half of the approved projects of the International Fund for Agricultural Development (IFAD) had a VCD-component.
} 
Given this gap, the purpose of this paper is to conceptualize integrated VCD and to provide evidence on its effectiveness. Based on transaction cost theory, the paper conceptualizes VCD as an intervention that aims to increase the functioning of a specific value chain by reducing transaction costs and by supporting specific value chain actors. The paper proceeds with a detailed illustration of an integrated VCD project called "SAFAL," which directly intervenes in the aquaculture, horticulture, and dairy sectors in South-West Bangladesh. It uses a flexible approach that intends to identify and tackle all constraints in the value chain that are binding farmers in accessing technology and output markets. The general strategy is to first identify a demand downstream in the value chain and then to identify and reduce the constraints experienced by actors upstream to meet this demand by offering financial and technical support and by reducing the transaction costs in the chain. SAFAL is representative for a large group of donor-funded integrated VCD projects, but is considered particularly flexible, intensive, and integrated, also in comparison to other integrated VCD projects (IOB 2017).

Finally, the paper assesses the effect of SAFAL on the farm income and food security of participating farmers. In the estimation, SAFAL is necessarily treated as a "black box. It is not possible to investigate the effects of different components of the project, because it is multifaceted project that intervenes at different stages of the value chain and project implementation is customized to the needs of the value chain actors. To overcome program placement and selfselection bias, the methodology relies on a matched difference-in-differences (MDID) estimator. The key assumption underlying a difference-in-difference estimator is that in absence of the project the average outcomes for the control and treatment group would have moved in parallel direction. To improve the comparability through time, project participants are matched with control farmers based on observable pre-project characteristics. Using this methodology, it is estimated that the project has, on average, increased the net-farm income of farmers by 
USD 404 and reduced the length of the hungry season experienced by participating households by about 12 days.

This paper contributes to a growing literature on the effectiveness of development interventions in reducing or overcoming market constraints experienced by farmers. This is a diverse literature which looks at different approaches, including technical and financial support to farmers (e.g., Ebata and Huettel 2019; Carter, Tjernström, and Toledo 2019), certification (e.g., Kersting and Wollni 2012; Ruben 2017), and infrastructure (e.g., Negi et al. 2018). The majority of the interventions studied by these articles are, however, "singular focused" (Christiaensen and Vandercasteelen 2019): the extent to which they represent an integrated solution to improve the functioning of a value chain is limited.

This paper also relates to a literature on contract farming, farmer cooperatives, and other value chain innovations, which suggests that re-organization of the value chain can help farmers to overcome market imperfections, improve their access to modern technologies and (highvalue) market outlets, and increase their income (Bellemare and Bloem 2018; Grashuis and Su 2019; Swinnen and Kuijpers 2019; Ton et al. 2018;). Many articles in this literature describe the role of NGOs in supporting contract farming schemes and farmer cooperatives. Fischer and Qaim (2012) and Kabunga et al. (2014), for example, describe how NGOs have supported farmer groups in the Kenyan banana sector by facilitating linkages with laboratories and nurseries for tissue culture and by linking farmers to urban wholesalers. Maertens and Vandevelde (2017) describe how an NGO financed the start-up of a semi-commercial contract farming scheme in the rice sector of Benin. Some of these papers provide empirical evidence that NGOs indeed play a role in linking farmers to markets (e.g., Andersson et al. 2015; Michelson 2013; Rao and Qaim 2011), but the literature mostly focuses on the welfare effect of "being linked" rather than on the welfare effects of the NGO intervention (the linking process). 
There are some important exceptions: some studies do rigorously estimate the farmer welfare effects of integrated VCD projects. Ashraf et al. (2009), for example, estimate the effects of a NGO-led outgrower scheme that trained Kenyan horticulture farmers and linked them to banks, providers of inputs, transportation services, and exporters. Using a randomized controlled trial they find that the project led to a $32 \%$ higher income for first-time exporters. Another example is by Biggeri et al. (2018) who study the impact of an integrated VCD project in the Ethiopian wheat value chain. The project provides farmers and cooperatives with technical training, access to better wheat varieties, and assets, and established contracts between cooperatives and pasta makers and between cooperatives and the farmers. Using cross-sectional observational data and an instrumental variable as identification strategy, they find that the project has led to $102 \%$ higher net-farm income among participating farmers.

This paper makes at least three contributions to this body of literature. First, it provides additional evidence on the effectiveness of integrated VCD as a policy instrument. SAFAL is a particularly interesting case as it intervenes at all stages of the value chain and thus uses a highly integrated approach. It does not only provide technical and financial support to farmers and farmer groups, but also to other actors in the chain and supports the emergence of new (micro-)business if there are missing links. Contextually the project is also interesting as it focuses on a diverse range of farm products (fish, dairy, fruits, and vegetables) in a highly dynamic region of Bangladesh. Secondly, the paper makes methodological contributions by using a credible matched difference-in-difference estimator (which is an improvement to studies based on cross-sectional observational data), by estimating the effects on food security, and by including a cost-benefit analysis. Finally, it makes a conceptual contribution by describing, in detail, the theory of change of SAFAL and by embedding this in a conceptualization of VCD based on transaction cost theory. This provides insight into what "linking" value chain actors or "improving linkages" in value chains entails. 
The finding that SAFAL is effective suggests that high transaction costs constrain the transformation of value chains and that this can have implications for farmer welfare. It also suggests these transaction costs can be reduced or overcome through an integrated VCD approach. In this sense our findings contribute to the broader literature on the importance of wellfunctioning value chains for agricultural productivity, structural transformation, and poverty reduction (Barrett et al. 2019; Fuglie et al. 2019; Reardon et al. 2009; Swinnen 2007; Swinnen and Kuijpers 2020).

\section{Value chain development in theory and practice}

Traditionally, the exchange of farm inputs and farm produce in agri-food value chains has been based on spot-markets (Reardon et al. 2009; Barrett et al. 2019). Spot-markets might, however, involve high transaction costs; possibly to such extent that some actors effectively have no access to these markets (e.g., Alene et al. 2008; De Janvry, Fafchamps, and Sadoulet 1991; Key, Sadoulet, and De Janvry 2000; Winter-Nelson and Temu 2005). ${ }^{2}$

High transaction costs at one stage (e.g., on the farm technology market) can affect the functioning of the entire value chain: the ability of the chain to comply with public or private requirements, such as regarding product quality, food safety, or ethical and environmental standards (value chain effectiveness) and the costs incurred in the value chain to bring forward the final product (value chain efficiency).

\footnotetext{
${ }^{2}$ Transaction costs can include costs incurred ex-ante, such as searching trade partners and obtaining information on prices, product attributes, and private standards; costs incurred during the transaction, such as transportation and storage costs and tariffs; and costs incurred ex-post, such as monitoring and enforcement costs (Hobbs 1997; North 1990). These transaction costs are expected to be higher for value chains that adhere to more stringent public or private standards, as these require more detailed and regular information transmission (Pingali, Khwaja, and Meijer 2005) and investments in specific technologies and practices to comply with these standards (Kuijpers and Swinnen 2016).
} 
Value chain development is a catch-all term for interventions that aim to improve value chain functioning. More specifically, it can be understood as an intervention that aims to increase the effectiveness or efficiency of a specific value chain by reducing the transaction costs between different stages and/or by supporting actors in the chain. It typically entails the introduction of institutional arrangements, other than spot-markets to coordinate exchange-also called value chain innovations - including interlinked contracting, farmer cooperatives, and vertical integration. These value chain innovations can lower transaction costs and can enable farmers to adopt the technology necessary to meet the requirements of buyers (Swinnen and Kuijpers 2019; Williamson 1991).

VCD can — in principle — be initiated by the firms in the value chain themselves. Investments in value chain innovations can be profitable if farmers face imperfect technology markets, but this depends on the surplus generated, the holdup opportunities in the chain, and the type of technology investments that are necessary (Kuijpers and Swinnen 2016). If private investments to improve value chain functioning are not feasible, the value chain can get stuck in a low-level equilibrium with low technological investments, little coordination, and products that do not meet consumer preferences.

Policies to improve the business environment in which the value chain actors operate are widely considered a first-best option to improve value chain functioning (e.g., Fuglie et al. 2019; Townsend et al. 2018; World Bank 2005). It is common, however, for policies and programs to also directly intervene in specific value chains to stimulate their development. There are at least three distinct approaches observed in practice. First, programs can finance and facilitate multi-stakeholder platforms that could improve coordination between value chain actors by simply bringing them together (see e.g., Devaux et al. 2009; Cavatassi et al. 2011). Second, programs can offer grants, concessional loans, or engage in public-private partnerships 
(PPPs) to/with lead firms for the introduction of value chain innovations (see e.g., IOB 2017; Ragasa et al. 2018; Maertens and Vandevelde 2017). Third, programs can finance NGOs who provide direct support to key value chain actors (see e.g., Ashraf et al. 2009; Biggeri et al. 2018). Compared to more traditional approaches, such as farmer extension schemes, these investments are typically made in anticipation of demand for products that meet certain requirements or are based on agreements with buyers. The SAFAL project in Bangladesh-introduced in the next section-illustrates this approach.

\section{Project description and intervention logic ${ }^{3}$}

\subsection{Project description}

The Sustainable Agriculture, Food Security and Linkages project (SAFAL) directly intervenes in key stages and linkages in the aquaculture, horticulture, and dairy value chain in the districts of Khulna and Jessore in South-West Bangladesh. It is financed by the Netherlands Ministry of Foreign Affairs and implemented by the NGO Solidaridad. ${ }^{4}$ The goal of SAFAL is to improve the welfare and food security of about 58,000 smallholders. To achieve this, the project uses a flexible intervention logic to tackle all binding constraints faced by these farmers in accessing markets. Concretely, the project activities can be grouped in four components. ${ }^{5}$

First, the project facilitates the formation of 1000 producer groups (500 in aquaculture, 300 in dairy, and 200 in horticulture) with about 45 to 60 members each. The project uses an inclusive approach by allowing all households in the community that were active in a given

\footnotetext{
${ }^{3}$ Information in this section is obtained from official documentation such as project proposals, annual reports, newsletters, and the mid-term review and input from project staff in August 2013, January 2014, September 2016, and May 2019.

${ }^{4}$ Financing was approved in November 2012. The first year and a half were primarily used to hire staff, fine tune the intervention strategy, signing MoU's with private companies, selecting project areas and program participants, and forming producer groups. Further implementation started in March 2014.

${ }^{5}$ This categorization is made by the author of this paper. On top of the four components described in the text the project also included a nutrition awareness and knowledge training.
} 
sub-sector (either aquaculture, dairy, or horticulture) to participate in a producer group, regardless of their farm size or other characteristics. Every two producer groups is led by one "lead farmer" elected by the group members. These lead farmers are trained by the project in producer group management and are given intensive sub-sector specific training on production and marketing practices, such that they can act as service providers for their producer groups (e.g., testing of water quality, de-worming of cattle, advising on the use of organic pesticides).

The second component consists of farmer training and the promotion of new farming practices. The training is generally conducted by lead farmers together with field organizers. See Table 1 for a list of training topics by sub-sector. In addition, the project collaborated with farmers in setting up about 600 demonstration plots for displaying the benefits of existing technologies and about 120 pilot plots for the testing and promotion of novel technologies.

Within the third component, the project provides support to small-scale entrepreneurs in providing services to farmers in the community. This includes the lead farmers who provide fee-based services and farm inputs to farmers, agro-input shops, community livestock service providers, mobile agro-input sellers, cooled transport services, feed and organic fertilizer production, and collection centers. These entrepreneurs are supported financially (e.g., shop construction, stocking of products, provision of vans and rickshaws) and technically (i.e., training on the products and services they are providing) and are brought into contact with farm input companies with whom the project negotiated prices (see the fourth component below).

The fourth component consists of the representation of the producer groups and the micro- and small enterprises by the project (described under component 3 ) in coordination and negotiation activities with farm input companies and potential buyers, such as traders, processors, and retailers (see Table 1). This entails searching these companies, negotiating contract terms, and engaging in agreements. With retail companies, processors, and traders the project 
Table 1: Overview of project activities divided by component and sub-sector.

\begin{tabular}{|c|c|c|c|c|}
\hline \multirow{2}{*}{\multicolumn{2}{|c|}{ Component }} & \multicolumn{3}{|c|}{ Sub-sector } \\
\hline & & Aquaculture & Dairy & Horticulture \\
\hline 1. & $\begin{array}{l}\text { Producer } \\
\text { groups }\end{array}$ & $\begin{array}{ll}- & \text { Facilitating formation of producer groups } \\
\text { - } & \text { Facilitating election lead farmer and executive com- } \\
\text { mittee } \\
\text { - } & \text { Training lead farmers and executive committee }\end{array}$ & $\begin{array}{ll}- & \text { Facilitating formation of producer groups } \\
\text { - } & \text { Facilitating election lead farmer and executive com- } \\
\text { mittee } \\
\text { - } & \text { Training lead farmers and executive committee }\end{array}$ & $\begin{array}{ll}- & \text { Facilitating formation of producer groups } \\
\text { - } & \text { Facilitating election lead farmer and executive com- } \\
\text { mittee } \\
\text { - } & \text { Training lead farmers and executive committee }\end{array}$ \\
\hline 2. & $\begin{array}{l}\text { Farmer } \\
\text { Training }\end{array}$ & 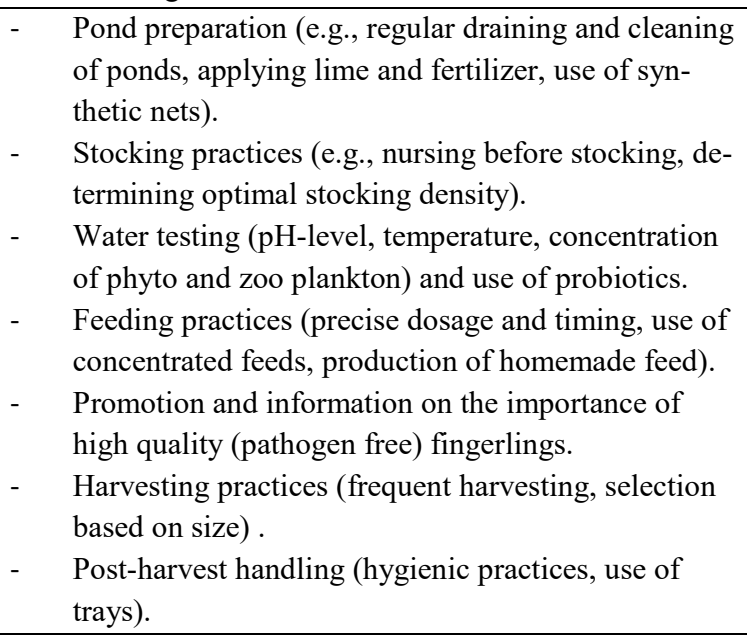 & $\begin{array}{l}\text { Hygienic milking and handling (hand washing, } \\
\text { cleaning udder, immediate transport to collection } \\
\text { center). } \\
\text { - Feed practices (e.g., use of concentrated feed and } \\
\text { green grasses, production of homemade feed) } \\
\text { - Improved shed management. } \\
\text { - } \quad \text { Promotion of deworming, vaccination, and medical } \\
\text { check-ups. } \\
\text { - Promotion of AI and cross-breeds. }\end{array}$ & $\begin{array}{l}\text { - } \begin{array}{l}\text { Promotion of organic fertilizer (vermicompost, com- } \\
\text { post). } \\
\text { - }\end{array} \\
\text { Promotion of safe and natural pest management } \\
\text { technologies such as sex pheromone traps and bio } \\
\text { pesticides. } \\
\text { - Promotion of post-harvest practices (e.g., harvesting } \\
\text { at maturity, protected storing, washing, grading, } \\
\text { sorting, packaging (using paper), protected transport } \\
\text { (using crates)). }\end{array}$ \\
\hline 3. & $\begin{array}{l}\text { Support to } \\
\text { farm service } \\
\text { providers }\end{array}$ & $\begin{array}{ll}- & \text { Lead farmers (selling inputs, technical support) } \\
- & \text { Collection centers } \\
- & \text { Cooled transport services } \\
- & \text { Fish food producers }\end{array}$ & $\begin{array}{ll}- & \text { Lead farmer (selling inputs, technical support) } \\
- & \text { Collection centers } \\
- & \text { Local input shops (feed, medicine) } \\
- & \text { Community livestock Service providers (deworm- } \\
& \text { ing, vaccination, medical check-ups, medicines) } \\
- & \text { Fodder and silage production } \\
- & \text { Milk transportation }\end{array}$ & $\begin{array}{ll}- & \text { Lead farmer(selling inputs, technical support) } \\
\text { - } & \text { Collection centers } \\
\text { - } & \text { Nurseries } \\
\text { - } & \text { Local input shops } \\
\text { - } & \text { Vegetable Collectors and sellers } \\
\text { - } & \text { Organic compost producers }\end{array}$ \\
\hline 4. & $\begin{array}{l}\text { Coordination } \\
\text { activities with } \\
\text { agribusiness }\end{array}$ & $\begin{array}{l}\text { - With hatcheries 'R. Rahman' and 'Anik Hatchery' } \\
\text { to supply farmers with high quality pathogen free } \\
\text { post larvae (incl. discounts and credit facilities) } \\
\text { With processor/exporter M.U. Seafood (incl. estab- } \\
\text { lishment and support to collection center) }\end{array}$ & $\begin{array}{l}\text { - With dairy processor BRAC (establishment of five } \\
\text { dairy collection centers, payment based on fat con- } \\
\text { tent, feed discount) } \\
\text { - With Winning Agro, a company providing calf man- } \\
\text { agement solutions (financing pilots) } \\
\text { - With DLS for artificial insemination services }\end{array}$ & $\begin{array}{l}\text { With supermarket AGORA and other retailers and } \\
\text { domestic traders (incl. transport support, provision } \\
\text { of crates) } \\
\text { - Several providers of seeds, chemicals, and equip- } \\
\text { ment (discounts, cost-sharing of demo-plots, train- } \\
\text { ing support) }\end{array}$ \\
\hline
\end{tabular}


entered into agreements about product and process requirements, payment-schemes, and potential (co-)investments in transport, collection, and packaging. With input companies the project entered into agreements regarding the distribution of quality inputs, discounts on agri-inputs, and (co-)investments in training and demonstration plots.

\subsection{Intervention Logic}

Central to the project is the immediate objective of improving farmer access to technology and to output markets by reducing transaction costs. ${ }^{6}$ The project is expected to reduce these transaction costs in at least three ways. First, the formation of producer groups (component 1) reduces the costs for buyers in dealing with a large number of farmers individually. In essence, it allows a portion of the transaction costs to be divided over a larger number of farmers. For example, it can reduce the per-farmer costs incurred for searching partners, obtaining information, negotiation, writing up contracts, transport, and contract enforcement. In addition, collective negotiation can lead to discounts on inputs, which essentially makes them better accessible. Secondly, by organizing farmers and by representing them in coordination activities with agribusinesses (component 4), the project incurs part of the one-time fixed transaction costs of entering into agreements that would otherwise fall on the farmers themselves. This includes the costs of searching partners, negotiation, and enforcement of agreements. And finally, by assisting farmer service providers the project reduces the distance farmers have to travel to purchase inputs or services or sell their produce to a certain market outlet (component 3).

Enhanced access to services and farm inputs, in combination with farmer training, is expected to enhance the ability of farmers to change their production and post-harvest practices. Besides increasing productivity and total production, the project intends to enable farmers such that they can meet buyer requirements. To this end, the project, for example, promoted

\footnotetext{
${ }^{6}$ See Figure A1 in the supplementary appendix for a schematic overview of the intervention logic.
} 
practices such as sex pheromone traps and organic pesticides; washing, grading and sorting of vegetables; protected and hygienic storage of produce; the use of pathogen-free post larvae; regular selective harvesting in aquaculture; and improved cow feeding practices to increase fatcontent in milk. The use of these practices is expected to increase access to high-value market outlets (supermarket or export channels) and to increase prices received by farmers. In turn, access to output markets and the possibility of obtaining higher prices for produce also provides an incentive to farmers to invest and change practices.

A second aspect that is central to the project is the simultaneous use of a push and pull strategy: value chain actors are both incentivized and enabled to invest and change their practices. This is done by first identifying the needs from actors downstream in the value chainexporters, retailers, or processors - and agreeing on the conditions under which they will procure produce from the farmers supported by the project. This step ensures that actors upstream in the chain have an incentive to comply with buyer requirements. The project can then identify and tackle the factors constraining these actors to meet these requirements.

This approach can be illustrated by SAFAL's activities in the mango sector. The project first entered into an agreement with the domestic retailer Agora to introduce a high quality pesticide free mango variety on the shelves of the supermarkets of Dhaka. As the demand for pesticide-free mangoes is high and the supply low, Agora was willing to provide farmers with a price premium. The project supported their mango producer groups to meet Agora's requirements by promoting the adoption of organic pesticides, pheromone traps (to capture insects), and post-harvest practices (i.e., hygienic handling of produce, grading, sorting, and packaging). To achieve this, farmers were in need of services (e.g., collection centers and transport services) and farm inputs (e.g., pheromone traps and organic pesticides). This, in turn, provided an incentive for entrepreneurs to invest and provide these inputs. To ensure that they are able to do 
this the project supported these entrepreneurs financially and technically and negotiated discounts with the farm input companies.

\subsection{Project Context}

SAFAL is operating in a particularly conducive context with high demand and growth in producer prices for aquaculture, horticulture, and dairy products, and rapidly transforming value chains. The agricultural sector in Bangladesh, which is still dominated by rice (Headey and Hoddinott 2016), is transforming rapidly. Increased rice productivity in combination with high economic growth and urbanization has increased consumer demand and prices for fish, vegetables, fruits, meat, and dairy (Sur and Zaman 2008). As a result, Bangladesh is now moving away from rice monoculture and towards a more diversified agri-food sector, with a more dominant role for aquaculture and horticulture. ${ }^{7}$

The most spectacular transformation is taking place in aquaculture. Since 1995, aquaculture production increased sevenfold. ${ }^{8}$ This growth in production went hand in hand with a transformation of the aquaculture value chain (Hernandez et al. 2018). This included commercialization of aquaculture farmers with increased use of purchased inputs, such as fingerlings, manufactured feed, and chemicals, and growth among the non-farm companies in the fish value chain, such as hatcheries, nurseries, feed mills, feed dealers, and traders.

Although less rapidly than in aquaculture, there has also been strong growth in horticulture. In fact, between 1995 and 2016, the production of vegetables and fruits grew by about $260 \% .{ }^{9}$ The growth in horticulture supply has, however, been unable to meet the growth in

\footnotetext{
${ }^{7}$ See Figure A2 in the supplementary appendix for a graph showing the development of rice productivity and the production of aquaculture, dairy, and horticulture over time.

${ }^{8}$ Based on FAO - Fisheries and Aquaculture Information and Statistics Branch (accessed on 06/04/2018).

${ }^{9}$ Based on FAOstat data accessed on 06/04/2018.
} 
domestic demand. As a result, producer prices for important horticultural products increased sharply in the past 15 years. ${ }^{10}$

Unlike aquaculture and horticulture, dairy production in Bangladesh has been stagnant in the past decades. Milk yields are extremely low in international comparison and have not improved since $1995 .{ }^{11}$ Meanwhile, there is a growing domestic demand for milk products and milk prices have increased sharply since $2005 .{ }^{12}$

\section{Identification Strategy}

The goal is to estimate the average effect of SAFAL on participating farmers. This effect is defined as the average difference in the observed outcome for farmers participating in the project and the outcome that would have been observed if these farmers would not have participated (i.e., the counterfactual). Using the potential outcome framework (Roy 1951; Rubin 1974; Splawa-Neyman, Dabrowska, and Speed 1990), this can be written more formally as

$$
\gamma=E[Y(1) \mid D=1]-E[Y(0) \mid D=1],
$$

with $\gamma$, the average effect on project participants, $D$ the participation status (equal to one if the farmer is a participant and equal to zero otherwise), and $Y(D)$, the potential outcome as a function of participation. Because the counterfactual $(Y(0) \mid D=1)$ is unobserved (by definition), it must be estimated. This is done by using outcomes observed for farmers that did not participate in the project (a control group).

\footnotetext{
${ }^{10}$ For example, the annual producer prices (in USD) for onions, tomatoes, and mangoes grew, respectively, by a factor 1.66, 2.25, and 2.38 between 2003 and 2017 (author calculations based on data obtained from FAOstat on 25 april 2019).

${ }^{11}$ Average yields have been at 205 liter milk per year per animal for the past twenty years. In comparison, average milk yield in Uganda, India, and the Netherlands is, respectively, a factor two, eight, and forty higher (FAOstat).

${ }^{12}$ Producer prices for cow milk increased by $70 \%$ between 2004 and 2016 (author calculations based on data obtained from FAOstat on 25 april 2019).
} 
A random selection of control farmers is, however, expected to be different in observable and unobservable ways from project participants, making a simple comparison of outcomes biased. There are two reasons why this is the case. First, the NGO decided in which communities the project is implemented and which farmers are eligible for participation. It does this based on a number of criteria. The community, for example, should contain an adequate number of small farmers in a given sub-sector (aquaculture, dairy, or horticulture) willing to participate in a producer group, it should have sufficient potential for improving production and marketing practices, and it should be relatively food insecure. Farmers are only eligible for participation if they are active in either aquaculture, dairy, or horticulture and willing to form a group. Not taking this into account can lead to so called program placement bias at the village and farmer level. Secondly, as participation is voluntary, farmers "self-select" as participants in the project. It is likely that farmers who decide to participate are different from those farmers that decide not to participate in ways that are observable (e.g., age, land size, or productivity) and unobservable (e.g., entrepreneurial ability, risk preferences, and locus of control). In other words, participation is not random.

To overcome program placement and self-selection bias, this paper relies on a matched difference-in-differences (MDID) estimator (Heckman et al. 1998). Following Heckman et al. (1997) and Smith and Todd (2005), this estimator is given by:

$$
M D I D=\frac{1}{n_{1}} \sum_{p \in N_{1}}\left\{\left(Y_{p, t=1}-Y_{p, t=0}\right)-\sum_{c \in N_{0}} W(p, c)\left(Y_{c, t=1}-Y_{c, t=0}\right)\right\}
$$

where $Y$ is the outcome of interest, $p$ is an individual participant in the set of project participants $N_{1}$ that are included in the estimation, $c$ is an individual control farmer in the set of control farmers $N_{0}, n_{1}$ is the number of participants in the set $N_{1}$, and $t$ is the time with $t=0$, the start of the project and $t=1$, the end of the project. The weights $W(p, c)$ are obtained through a matching procedure. 
Like a normal difference-in-differences estimator (without matching) MDID compares the difference in outcome before and after the project between a group of participants and a control group. This allows for controlling for unobservable time-invariant farm characteristics that are related to both the participation-decision and the observed outcomes. The key assumption underlying a difference-in-difference estimator is that in absence of the project the average outcomes for the control and treatment group would have moved in parallel direction. This assumption is less likely to be valid if the participants and control farms have different preproject characteristics, because this might cause different reactions to common trends and shocks, such as to weather shocks, infrastructural development, or the economic-boom in the aquaculture sector (Abadie 2005).

To improve the comparability through time, project participants are matched with control farmers based on observable pre-project characteristics. ${ }^{13}$ This is done based on the propensity score $e(X)=\operatorname{Pr}(D=1 \mid X)$ : the probability that a farm participates in the project conditional on observable farm characteristics $X$. Rubin and Rosenbaum (1983) showed that if potential outcomes are independent of participation conditional on covariates $\mathrm{X}$, they are also independent of participation conditional on the propensity score $e(X)$.

To calculate the propensity scores I run a probit regression with participation $(0$ or 1$)$ as dependent variable and a list of covariates (pre-project farm household characteristics) that are expected to influence both participation and the outcomes of interest. The propensity score for each household is then obtained by taking the predicted value of the estimated probit model.

\footnotetext{
${ }^{13}$ Both village and farmer level characteristics are used to match control and treatment farmers. Matching thus helps in reducing bias as a result of village and farmer program placement and self-selection. An additional way in which program placement bias is reduced is by selecting the sampling area for control farmers that match the characteristics of project areas in terms location (i.e., by using neighboring regions), agricultural production structure, and geography. See Section 5 for more details.
} 
The covariates included in the model cannot be affected by participation in the project. To ensure this, they should therefore either be constant over time or measured before the start of the project (Caliendo and Kopeinig 2008). In addition, it should be taken into account that omitting important covariates can increase bias in estimating the effectiveness, while including too many unimportant covariates can increase the variance of the propensity score (see Heckman et al. (1997), Dehejia and Wahba (1999), and Bryson et al. (2002) cited in Caliendo and Kopeinig (2008)). With this in mind, I included the pre-project age, gender, and education of the household head, the size of the household, the distance of the household to the main road, whether the farmer produced any dairy, horticulture, or aquaculture products in the year before participation, the size of the land owned by the household, the length of the hungry season, yearly wage income, yearly income from renting out land, the percentage of production sold, total production value, and farm expenditures.

Kernel matching is used to obtain the weights $W(p, c)$ in equation (2). This procedure matches each participant with a weighted average of all control observations (see Heckman et al. (1997) and Caliendo and Kopeinig (2008) for more details). ${ }^{14}$ It gives a higher weight to those control farmers that have a propensity score closer to the propensity score of the participant.

Only those observations are included that are within the common support. This means I drop the observations from the control group that have a propensity score lower than the minimum propensity score in the group of participants and those observations from the group of participants that have propensity score higher than the maximum propensity score in the control group.

\footnotetext{
${ }^{14}$ More precisely, using an epanechnikov kernel function and a bandwidth of 0.05 , the weight of a control household that is matched to one project participant is given by$$
W(p, c)=\frac{3}{4}\left(1-\left(\frac{e\left(X^{p}\right)-e\left(X^{c}\right)}{0.05}\right)^{2}\right) / \sum_{k \in N_{0}} \frac{3}{4}\left(1-\left(\frac{e\left(X^{p}\right)-e\left(X^{k}\right)}{0.05}\right)^{2}\right), \text { with }\left|\frac{e\left(X^{p}\right)-e\left(X^{c}\right)}{0.05}\right| \leq 1 .
$$ 
Finally, I rely on the following weighted linear regression model to obtain the MDID estimator:

$$
Y_{i t}=\beta_{0}+\beta_{1} t+\beta_{2} D_{i}+\beta_{3} D_{i} * t+e_{i}
$$

where $\beta_{3}$ is the MDID estimate of the project effect, obtained using weights equal to unity for participants and equal to $\sum_{p \in N_{1}} \sum_{c \in N_{0}} W(p, c)$ for the control households. Standard errors are obtained by bootstrapping (1000 repetitions). Each repetition includes the re-estimation of propensity scores, kernel matching, dropping of observations outside the common support, and a re-estimation of equation (3) using the newly obtained weights. ${ }^{15}$

One limitation of the matched difference-in-difference estimator is its inability to explicitly control for unobserved time-variant heterogeneity. This threatens the validity of the parallel trends hypothesis. However, by matching the project group with the control group we make it more likely that common shocks or trends impact the control and treatment groups in a similar way. Moreover, by selecting control areas close to treatment areas the two groups are, at least to some extent, exposed to similar shocks and trends (see next section).

\section{Data}

\subsection{Survey}

The data used in this paper were collected in the project upazilla's (sub-districts) of Manirampur, Abhaynagar, Dumuria, and Paikgacha in April-June 2014 and 2016. These upazilla's were selected because implementation in these upazilla's would start immediately after the baseline survey. The survey was commissioned and financed by the Policy and Operations Evaluation Department of the Netherlands Ministry of Foreign Affairs (as part of a review of the food

${ }^{15}$ The main estimation uses stata package "diff” (Villa 2016). 
security policy of the Netherlands) and implemented by a consortium of APE, AIDEnvironment, and BRAC University / Development Research Initiative (DRI).

Figure 1: Map of surveyed project (solid grey) and control (dotted) unions.

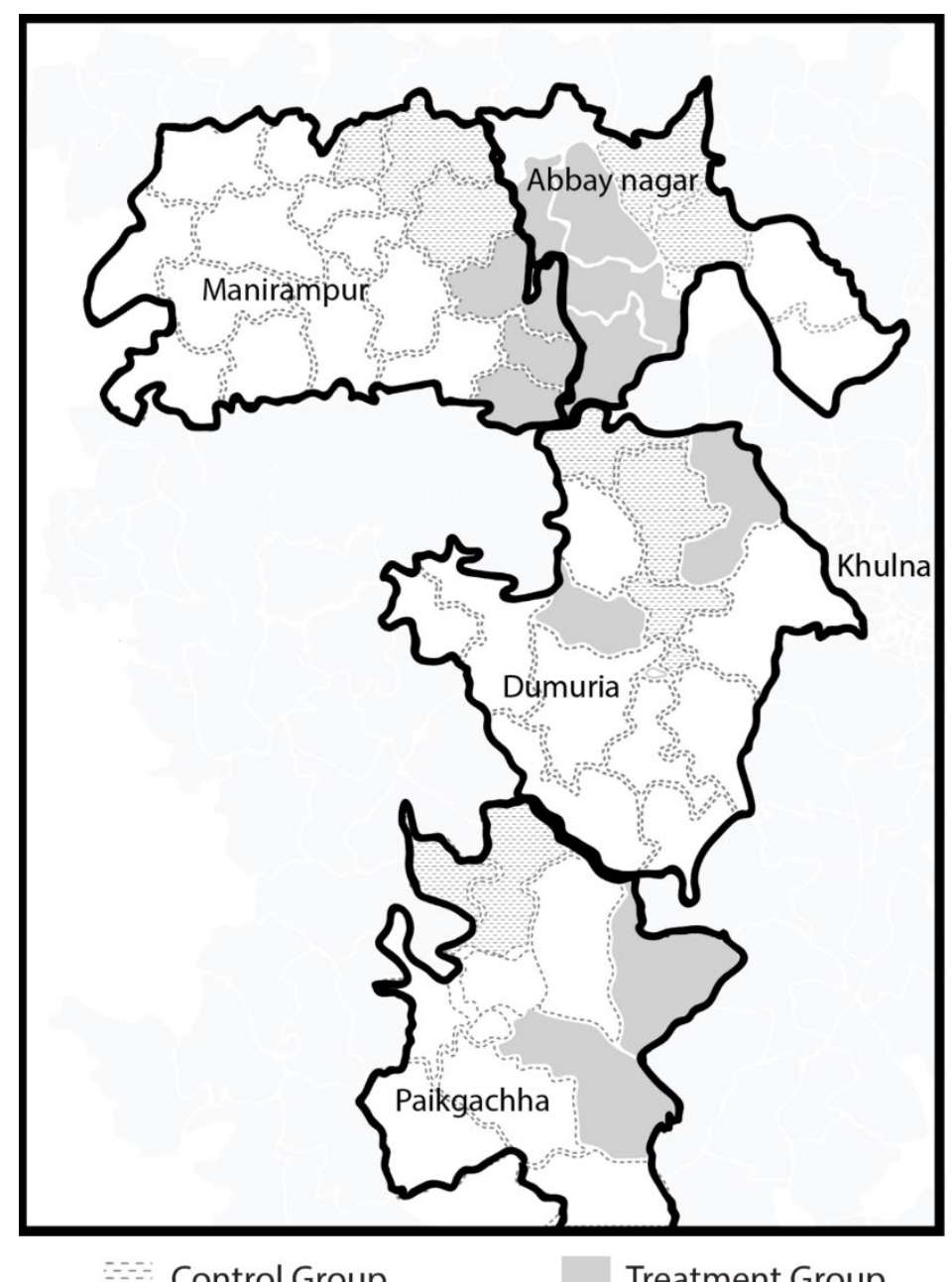

Within the project upazilla's, ten project unions were selected where SAFAL planned to start implementation immediately after the baseline survey: two in Dumuria, two in Paikgacha, three in Manirampur, and three in Abhaynagar. Then, to ensure comparability over time, each project union was matched with a nearby control union in the same upazilla with similar characteristics (such as agricultural production structure, nearness to a regional town, and geography). See Figure 1 for a map with the resulting selection of project and control unions. Although the control unions in the North are further from the district capital Khulna, they are 
in no sense more remote as they are close to the district capital of Jessore to the North (not on the map)

Households were selected using clustered random sampling at the village level. First, 27 project and 27 control villages were sampled randomly within the 10 project and control unions, respectively. Secondly, in each project village ten households were sampled randomly from a list of project participants. In the control village, ten households were sampled from a list of all households in the village that were active in either horticulture, aquaculture, or dairy. Project participants are thus defined as those farmers who were signed up to be participants in SAFAL at the time of the survey in 2014.

Spillover effects are taken into account by sampling the control households from different villages in different unions than the project participants. This reduces the probability that project participants and control households are part of the same or neighboring communities. This does not, however, rule out all potential spillover effects that could affect the control group. SAFAL might, for example, still positively affect the control group through better local availability of farm inputs, farm services, and market outlets also for non-participating farmers. SAFAL might also negatively affect the control group, for example, as a result of substitution of project farmers for non-project farmers as preferred suppliers by buyers of high-value products.

\subsection{Operationalization of outcome variables}

Following the intervention logic, I estimate the effect of the project on two impact-level indicators: net-farm income and the length of the hungry season. Net-farm income is defined as the 
value of farm production minus farm expenditures in US Dollar (USD). ${ }^{16}$ The value of production is the total quantity of fish, livestock products, and crops produced by the farm household in the year prior to the interview multiplied by medium prices in the pooled 2014 and 2016 sample. Median prices in the sample are used (instead of actual prices) to assign a monetary value also to those foods not sold by the household. This is particularly important given that about fifty percent of production is consumed by the farm household itself (see Section 5.3). Farm expenditures include expenses on seed, fertilizer, pesticides, labor, irrigation, fish feed, fingerlings, veterinary products/advice, and livestock feed.

The length of the hungry season is an adapted version of the commonly used months of adequate household food provisioning (MAHFP) indicator (Bilinsky and Swindale 2010). It is measured by asking the person most knowledgeable regarding food provisioning in the household (typically a woman) whether during the past twelve months he or she ever worried that the household would not have enough food. If this person responded with "yes", he or she is asked to recall in which months this was the case. The number of months they recall this was the case is what defines the length of the hungry season.

\subsection{Descriptive statistics}

Table 2 presents the 2014 descriptive statistics for the project participants and control group and a balance test. Four project participants and four control households could not be re-interviewed 2016. ${ }^{17}$ In addition, fourteen observations are dropped because they contained outliers

\footnotetext{
${ }^{16}$ Converted from Bangladeshi Taka (BDT) using the exchange rates at the time of the survey: 77.7 BDT/USD in 2014 and 78.3 BDT/USD in 2016.

${ }^{17}$ This attrition may be a source of bias if it is associated with project outcomes. Since the rate of attrition in this case is very low (1.4\%) and because it is present among both control and project households (and therefore less likely to be related to project outcomes), I do not correct for this in the estimation procedure.
} 
in terms of farm revenue. ${ }^{18}$ As a result, the total sample size used in the analysis contains 253 project participants and 265 control households.

Among the project participants, 175 households participated in a producer group around aquaculture, 54 in a producer group around dairy, and 42 in a producer group around horticulture. ${ }^{19}$ These households are spread out over 25 different aquaculture groups, 14 dairy groups, and 5 horticulture groups.

There are large differences between project participants and control households. In general, project participants tend to be better off as they have a higher farm revenue, a higher total production value, are better educated, own more land, and have higher output market participation. In addition, a (much) larger percentage of the project participants is a producer of aquaculture.

These differences in household characteristics are particularly important in light of our identification strategy. To reiterate Section 4, large pre-project differences make it less likely that the parallel trends assumption underlying the difference-in-difference estimation is valid. The fact that there are large difference in our case underlines the importance of matching the project participants with control farmers on pre-project characteristics.

In 2016, all farmers were asked whether they experienced an improvement in market access, access to technology, and prices. Project participants were more likely to report a positive change on all these aspects. About $92 \%$ of the project farmers reported to have experienced improvements in market access (vs. 64\% in the control group), $66 \%$ experienced better access to technologies (vs. $35 \%$ in the control group), and $83 \%$ experienced better prices (vs. $62 \%$ in

\footnotetext{
${ }^{18}$ The existence of outliers was determined using a histogram. All households that have a value beyond the 99th percentile in terms of farm revenue in either 2014 or 2016 are dropped. The estimation results are, however, also robust to the use of the full sample (see discussion on the robustness of the results in Section 6.2).

${ }^{19}$ Some households participate in multiple producer groups.
} 
the control group). Although this subjective reporting is not sufficient to conclude that the project has been successful, it does warrant a further investigation.

Table 2: Descriptive Statistics for Control and Project group

\begin{tabular}{|c|c|c|c|}
\hline Variables & $\begin{array}{c}\text { Control } \\
(1) \\
\end{array}$ & $\begin{array}{l}\text { Project } \\
(2) \\
\end{array}$ & $\begin{array}{c}\text { Difference, } p \text {-value } \\
\text { (3) }\end{array}$ \\
\hline $\begin{array}{l}\text { Household head age } \\
\text { (years) }\end{array}$ & $\begin{array}{l}49.211 \\
(0.673)\end{array}$ & $\begin{array}{l}48.783 \\
(0.818)\end{array}$ & 0.670 \\
\hline $\begin{array}{l}\text { Household head female } \\
\text { (dummy) }\end{array}$ & $\begin{array}{c}0.034 \\
(0.008)\end{array}$ & $\begin{array}{c}0.024 \\
(0.006)\end{array}$ & 0.289 \\
\hline $\begin{array}{l}\text { Household head education: } \\
\text { - Some primary } \\
\text { (dummy) }\end{array}$ & $\begin{array}{c}0.196 \\
(0.033)\end{array}$ & $\begin{array}{c}0.138 \\
(0.027)\end{array}$ & 0.189 \\
\hline $\begin{array}{l}\text { - Finished primary } \\
\text { (dummy) }\end{array}$ & $\begin{array}{c}0.121 \\
(0.018)\end{array}$ & $\begin{array}{c}0.083 \\
(0.014)\end{array}$ & 0.092 \\
\hline $\begin{array}{l}\text { - More than primary } \\
\text { (dummy) }\end{array}$ & $\begin{array}{l}0.370 / \\
(0.028)\end{array}$ & $\begin{array}{c}0.549 \\
(0.046)\end{array}$ & 0.002 \\
\hline $\begin{array}{l}\text { Land size owned } \\
\text { (hectare) }\end{array}$ & $\begin{array}{c}0.414 \\
(0.086)\end{array}$ & $\begin{array}{c}0.685 \\
(0.058)\end{array}$ & 0.015 \\
\hline $\begin{array}{l}\text { Household size } \\
\text { (\# of household members) }\end{array}$ & $\begin{array}{c}4.581 \\
(0.074)\end{array}$ & $\begin{array}{c}4.933 \\
(0.117)\end{array}$ & 0.014 \\
\hline $\begin{array}{l}\text { Wage income } \\
\text { (USD/year) }\end{array}$ & $\begin{array}{l}372.405 \\
(44.399)\end{array}$ & $\begin{array}{l}293.726 \\
(46.440)\end{array}$ & 0.227 \\
\hline $\begin{array}{l}\text { Income from land rent } \\
\text { (USD/year) }\end{array}$ & $\begin{array}{c}59.969 \\
(26.541)\end{array}$ & $\begin{array}{c}76.409 \\
(21.715)\end{array}$ & 0.629 \\
\hline $\begin{array}{l}\text { Milk Producer } \\
\text { (dummy) }\end{array}$ & $\begin{array}{c}0.117 \\
(0.034)\end{array}$ & $\begin{array}{c}0.190 \\
(0.040)\end{array}$ & 0.170 \\
\hline $\begin{array}{l}\text { Aquaculture producer } \\
\text { (dummy) }\end{array}$ & $\begin{array}{c}0.302 \\
(0.068)\end{array}$ & $\begin{array}{c}0.723 \\
(0.043)\end{array}$ & 0.000 \\
\hline $\begin{array}{l}\text { Horticulture producer } \\
\text { (dummy) }\end{array}$ & $\begin{array}{c}0.170 \\
(0.028)\end{array}$ & $\begin{array}{c}0.154 \\
(0.042)\end{array}$ & 0.751 \\
\hline $\begin{array}{l}\text { Distance to main road } \\
\text { (kilometer) }\end{array}$ & $\begin{array}{c}0.128 \\
(0.031)\end{array}$ & $\begin{array}{c}0.072 \\
(0.016)\end{array}$ & 0.123 \\
\hline $\begin{array}{l}\text { Share of production sold } \\
\text { (sold/produced) }\end{array}$ & $\begin{array}{c}0.308 \\
(0.036)\end{array}$ & $\begin{array}{c}0.516 \\
(0.039)\end{array}$ & 0.001 \\
\hline $\begin{array}{l}\text { Production value } \\
\text { (USD) }\end{array}$ & $\begin{array}{c}614.454 \\
(107.705)\end{array}$ & $\begin{array}{l}1476.137 \\
(230.100)\end{array}$ & 0.003 \\
\hline $\begin{array}{l}\text { Farm Revenue } \\
\text { (USD) }\end{array}$ & $\begin{array}{l}252.475 \\
(59.216)\end{array}$ & $\begin{array}{c}780.925 \\
(156.906)\end{array}$ & 0.006 \\
\hline $\begin{array}{l}\text { Farm expenditures } \\
\text { (USD) }\end{array}$ & $\begin{array}{l}259.424 \\
(48.150)\end{array}$ & $\begin{array}{l}511.150 \\
(84.282)\end{array}$ & 0.018 \\
\hline $\begin{array}{l}\text { Farm profit } \\
\text { (USD) }\end{array}$ & $\begin{array}{c}-6.949 \\
(27.472)\end{array}$ & $\begin{array}{l}269.775 \\
(79.130)\end{array}$ & 0.005 \\
\hline $\begin{array}{l}\text { Net farm income } \\
\text { (USD) }\end{array}$ & $\begin{array}{l}355.030 \\
(65.542)\end{array}$ & $\begin{array}{c}964.986 \\
(152.484)\end{array}$ & 0.002 \\
\hline $\begin{array}{l}\text { Length hungry season } \\
\text { (Months) }\end{array}$ & $\begin{array}{c}1.026 \\
(0.143)\end{array}$ & $\begin{array}{c}0.708 \\
(0.125)\end{array}$ & 0.109 \\
\hline $\mathrm{N}$ & 265 & 253 & \\
\hline
\end{tabular}

All standard errors are clustered at the union (primary sampling unit) level. 


\section{Estimation Results}

\subsection{Project participation and matching}

Figure 2 shows the distribution of the propensity scores of project participants and the control group. ${ }^{20}$ The two distributions are substantially different, with a much larger group of control farmers with low propensity scores. This further confirms the importance of matching prior to calculating the difference-in-difference estimator. Importantly, there is sufficient overlap of the distribution of the control group with the distribution of the project participants. This implies that there are project participants and control households with similar observable characteristics. Eleven households from the control group (on the low end of the distribution) and eighteen households from the treatment group (on the high end), however, fall outside the common support area and are dropped from the sample. The remaining sample that falls within the common support thus includes 255 control households and 234 project participants.

Figure 2: Distribution of propensity scores of project participants (solid line) and control group (dashed line).

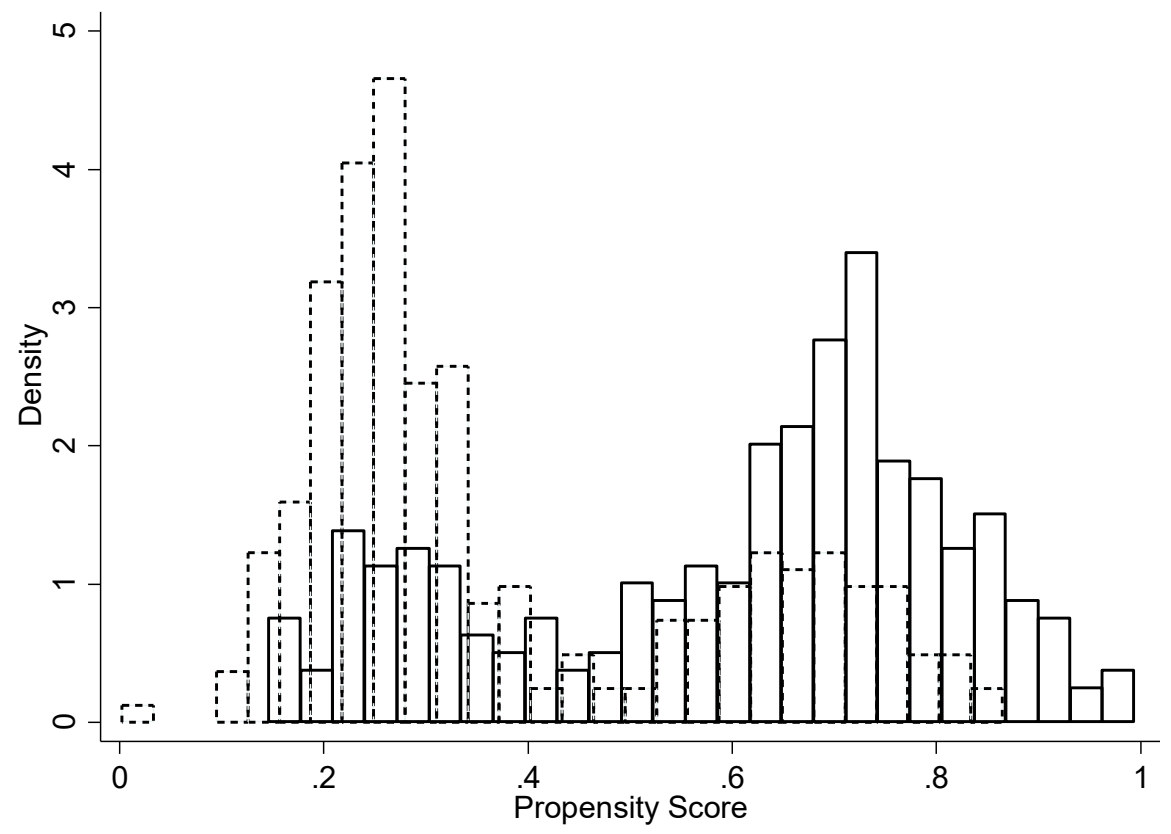

\footnotetext{
${ }^{20}$ The probit regression results that are used to calculate the propensity score weights can be found in the supplementary appendix
} 
Table 3 shows the descriptive statistics after the matching procedure. According to a two sample t-test, the two groups have become more similar in characteristics as result of the matching procedure. In fact, after applying the kernel weights, there are no statistically significant pre-project differences in average household characteristics remaining between the control and project group.

Table 3: Two sample means, differences, and t-statistic after kernel weighting

\begin{tabular}{|c|c|c|c|c|}
\hline Weighted Variable(s) & $\begin{array}{c}\text { Mean } \\
\text { Control } \\
(1) \\
\end{array}$ & $\begin{array}{c}\text { Mean } \\
\text { Participants } \\
(2) \\
\end{array}$ & $\begin{array}{c}\text { Difference } \\
\text { (3) }\end{array}$ & $\begin{array}{c}\text { t-statistic } \\
(4)\end{array}$ \\
\hline Household head age & 47.812 & 48.838 & 1.026 & 0.81 \\
\hline Household head female & 0.020 & 0.026 & 0.006 & 0.45 \\
\hline \multicolumn{5}{|l|}{ Household head education: } \\
\hline - Some primary & 0.163 & 0.145 & -0.018 & 0.54 \\
\hline - Finished primary & 0.085 & 0.081 & -0.004 & 0.15 \\
\hline - More than primary & 0.544 & 0.543 & -0.002 & 0.04 \\
\hline Land size owned & 0.700 & 0.641 & -0.060 & 0.85 \\
\hline Household size & 4.741 & 4.850 & 0.109 & 0.77 \\
\hline Wage income & 293.906 & 292.100 & -1.807 & 0.04 \\
\hline Income from land rent & 87.642 & 69.963 & -17.679 & 0.73 \\
\hline Milk Producer & 0.168 & 0.179 & 0.011 & 0.33 \\
\hline Aquaculture producer & 0.701 & 0.705 & 0.004 & 0.11 \\
\hline Horticulture producer & 0.192 & 0.167 & -0.025 & 0.73 \\
\hline Distance to main road & 0.081 & 0.076 & -0.005 & 0.41 \\
\hline Share of production sold & 0.504 & 0.495 & -0.008 & 0.27 \\
\hline Production value & 1244.403 & 1184.508 & -59.895 & 0.54 \\
\hline Farm expenditures & 499.319 & 468.940 & -30.379 & 0.66 \\
\hline Length hungry season & 0.628 & 0.645 & 0.017 & 0.13 \\
\hline
\end{tabular}

The T-tests are based on bootstrapped standard errors.

\subsection{Main results}

Using the kernel weights obtained through the matching procedure, Table 4 presents the 2014 and 2016 mean values for the two main indicators, the 2014 and 2016 differences between control and project group, and the double-difference estimate of the average project effect on 
the project participants. Before looking at the double-difference estimates, it is good to observe that the sample was balanced in 2014 in terms of pre-project outcomes (see column 3).

Table 4: Double difference estimation (after kernel matching) of effect on impact indicators.

\begin{tabular}{|c|c|c|c|c|c|c|c|}
\hline Outcome & $\begin{array}{c}\text { Mean } \\
2014 \\
\text { Control } \\
(1) \\
\end{array}$ & $\begin{array}{c}\text { Mean } \\
2014 \\
\text { Project } \\
(2) \\
\end{array}$ & $\begin{array}{c}\text { Difference } \\
2014 \\
(3) \\
\end{array}$ & $\begin{array}{c}\text { Mean } \\
2016 \\
\text { Control } \\
(4) \\
\end{array}$ & $\begin{array}{c}\text { Mean } \\
2016 \\
\text { Project } \\
(5) \\
\end{array}$ & $\begin{array}{c}\text { Difference } \\
2016 \\
(6) \\
\end{array}$ & $\begin{array}{c}\text { Double } \\
\text { Difference } \\
(8)\end{array}$ \\
\hline Net farm income & 745.1 & 715.6 & $\begin{array}{l}-29.52 \\
(130.9)\end{array}$ & 511.5 & 885.9 & $\begin{array}{l}374.4 * * \\
(159.5)\end{array}$ & $\begin{array}{l}403.9^{*} \\
(213.2)\end{array}$ \\
\hline $\begin{array}{l}\text { Length hungry } \\
\text { season }\end{array}$ & 0.628 & 0.645 & $\begin{array}{l}0.0170 \\
(0.126)\end{array}$ & 0.690 & 0.303 & $\begin{array}{c}-0.386^{* * * *} \\
(0.131)\end{array}$ & $\begin{array}{c}-0.403 * * \\
(0.180)\end{array}$ \\
\hline $\mathrm{N}$ (on common support) & 255 & 234 & & 255 & 234 & & \\
\hline
\end{tabular}

Bootstrapped standard errors in parentheses; ${ }^{* * *} \mathrm{p}<0.01,{ }^{* *} \mathrm{p}<0.05,{ }^{*} \mathrm{p}<0.1$.

The double-difference estimates (last column of Table 4) suggest that there is a high likelihood that the project had a positive effect on both our main indicators. According to our best estimation, project participation, on average, increased net-farm income by USD $404(P=$ $0.037)$ and reduced the length of the hungry season by about 0.4 months $(\mathrm{P}=0.023)$. Assuming 30 days per month, this would imply an average reduction in the time in which households feel food insecure of about 12 days. This is a reduction of about $62 \%$ compared to 2014 .

To investigate what explains this increase in farm income, I also estimate the effect of the project on the underlying variables: production value and farm expenditures (see Panel A of Table 5). The results indicate that the project led to an increase in production value by USD $704(P=0.011)$. As prices are kept constant in the calculation of production value (by using the sample median prices), the positive effect on production value suggests that the project led to higher production quantity or a shift towards higher value products. ${ }^{21}$ The results also indicate that the project led to an increase in farm expenditures by USD $300(P=0.015)$. A higher

\footnotetext{
${ }^{21}$ Due to the highly mixed farming systems common in Bangladesh production in terms of weight cannot be used as sensible indicator.
} 
use of (purchased) farm inputs of higher quality was a project objective, so higher farm expenditures was expected. In fact, it might be the case that production went up because of higher farm expenditures.

Table 5: Double difference estimation of project effects on other indicators.

\begin{tabular}{|c|c|c|c|c|c|c|c|}
\hline Outcome & $\begin{array}{c}\text { Mean } \\
2014 \\
\text { Control } \\
(1) \\
\end{array}$ & $\begin{array}{c}\text { Mean } \\
2014 \\
\text { Project } \\
(2) \\
\end{array}$ & $\begin{array}{c}\text { Difference } \\
2014 \\
(3)\end{array}$ & $\begin{array}{c}\text { Mean } \\
2016 \\
\text { Control } \\
(4) \\
\end{array}$ & $\begin{array}{c}\text { Mean } \\
2016 \\
\text { Project } \\
(5) \\
\end{array}$ & $\begin{array}{c}\text { Difference } \\
2016 \\
(6) \\
\end{array}$ & $\begin{array}{c}\text { Double } \\
\text { Difference } \\
(8)\end{array}$ \\
\hline \multicolumn{8}{|l|}{ Panel A: } \\
\hline Production value & 1244 & 1185 & $\begin{array}{l}-59.90 \\
(161.2)\end{array}$ & 1232 & 1876 & $\begin{array}{c}643.9 * * * \\
(209.6)\end{array}$ & $\begin{array}{c}703.8 * * * \\
(261.2)\end{array}$ \\
\hline Farm expenditures & 499.3 & 468.9 & $\begin{array}{l}-30.38 \\
(62.1)\end{array}$ & 720.9 & 990.4 & $\begin{array}{c}269.5^{* *} \\
(106.9)\end{array}$ & $\begin{array}{c}299.9^{* *} \\
(121.4)\end{array}$ \\
\hline \multicolumn{8}{|l|}{ Panel B: } \\
\hline Farm revenue & 558.7 & 597.6 & $\begin{array}{c}38.93 \\
(103.4)\end{array}$ & 845.5 & 1356 & $\begin{array}{c}510.7 * * * \\
(166.6)\end{array}$ & $\begin{array}{c}471.7 * * \\
(198.0)\end{array}$ \\
\hline Farm profit & 59.38 & 128.7 & $\begin{array}{l}69.31 \\
(82.6)\end{array}$ & 124.7 & 365.8 & $\begin{array}{c}241.1^{* *} \\
(107.7)\end{array}$ & $\begin{array}{c}171.8 \\
(132.3)\end{array}$ \\
\hline \multicolumn{8}{|l|}{ Panel C: } \\
\hline Wage income & 293.9 & 292.1 & $\begin{array}{c}-1.81 \\
(47.48)\end{array}$ & 278.4 & 253.8 & $\begin{array}{c}-24.68 \\
(48.64)\end{array}$ & $\begin{array}{l}-22.87 \\
(67.90)\end{array}$ \\
\hline Income from land rent & 87.64 & 69.97 & $\begin{array}{l}-17.68 \\
(28.19)\end{array}$ & 106.4 & 88.66 & $\begin{array}{l}-17.77 \\
(29.25)\end{array}$ & $\begin{array}{c}-0.092 \\
(41.99)\end{array}$ \\
\hline $\mathrm{N}$ (on common support) & 255 & 234 & & 255 & 234 & & \\
\hline
\end{tabular}

Bootstrapped standard errors in parentheses; ${ }^{* * *} \mathrm{p}<0.01,{ }^{* *} \mathrm{p}<0.05,{ }^{*} \mathrm{p}<0.1$.

One shortcoming of the net-farm income indicator is that it does not account for higher prices received by the farmer (a project objective), because it uses medium prices to take into account production for own consumption. Therefore, I also estimate the effect of the project on farm revenue (total yearly earnings from the sale of crops, livestock products, and aquaculture based on the actual received prices instead of median prices) and on farm profit (farm revenue minus farm expenditures). The results are presented in Panel B of Table 5. It is estimated that project participation, on average, increased farm revenue by USD $472(P=0.017)$ and farm profits by USD $172(P=0.243)$. The lower coefficient for farm profits, in combination with a high standard deviation, means that there is quite some uncertainty regarding the 
estimated effect, which means I cannot confidently reject the hypothesis that the effect on farm profits is close to zero. The reason why I find a clear positive effect on net-farm income and not on farm profit is that net-farm income also takes into account the effect of the project on the production value that is consumed by the household itself-which was, on average, about $50 \%$ of the total value of production in 2014 (see Table 3 ).

Unfortunately, the data provides no reliable information on total household income. A more exact estimation of welfare effects, including the effect on off-farm income, is therefore not possible. There is, however, information on wage income and income from land rent that can give us some insight in some of the potential opportunity costs incurred by the farmers as a result of project participation. SAFAL might, for example, have led to the application of more labor-intensive technologies, which in turn might have led to reduced wage income. SAFAL might also have led to a reduction in the amount of land being rented out — as farming might have become relatively more profitable — and thus lower income from land rent. To test this, I estimate the effect of SAFAL on the wage income and income from land rent. The estimations, as presented in Panel $\mathrm{C}$ of Table 5, however, provide no evidence that the project affected wage income and land rent in any substantial way.

To summarize, our results indicate the project has led to a large increase in farm revenue but not to a statistically significant increase in farm profits - due to higher farm expenditures. The farm household did, however, benefit as a result of an increase in the value of productionwhich also takes into account the production consumed - that more than off-sets the increase in farm expenditures. There is no indication of high opportunity costs in terms of losses in wage or land rent income. This would suggest farmer welfare went up as a result of the project. The higher access to food from own consumption in combination with more welfare — and the cash income that can be spend on other items than food-likely contributed to the estimated positive effect on the length of the hungry season. 
The robustness of these findings is confirmed by estimating several alternative specifications, including alternative matching functions, different choice of matching variables, the use of inverse-hyperbolic-sine transformations for the continuous monetary variables, not trimming the farm revenue data, and dropping those participants that indicated in 2016 they have not been participating in a SAFAL producer group (see the supplementary appendix).

\subsection{Cost effectiveness}

The benefits of the project can only be evaluated against the costs that were made to achieve this benefit. The total project costs of SAFAL, for the period 2012 to 2016, amounted to USD $14,783,076{ }^{22}$ According to the project completion report (Solidaridad 2017), the project has supported a total of 58,717 farmers. The average expenditure per farmer reached is thus USD 251,77 .

The cost-benefit ratio of the project is sensitive to underlying assumptions. First, I assume that USD 251,77 is also what is spent, on average, per farmer in our sample. ${ }^{23}$ Secondly, I assume a social discount rate of $11 \%$, recommended by Jalil (2010) for public projects in Bangladesh. Finally, I need to make an assumption on the yearly recurrence of the project benefits. Simply assuming the estimated effects are recurring yearly and in perpetuity seems unrealistic, because there is uncertainty to what extent the project benefits continue also after the project ends (see e.g., Shanoyan et al. 2014). Among other things, this depends on the extent to which farmers that have not been part of the project are able to catch up, for example, as a result of the rapid transformation that is going on in the aquaculture and horticulture value

\footnotetext{
22 The budget was EUR 12 million. We use the average exchange rate between August 2012 and Aug 2016 (the project period): 1.231923 USD/EUR.

${ }^{23}$ This is not necessarily the case because the two sub-districts in which we sampled the farmers were the first two (out of five) where the project was rolled out. As the implementation did not end earlier in the sub-districts where implementation started earlier, the project has been active longer in the two sub-districts covered by our survey than in the other three sub-districts. Moreover, project staff knew we were evaluating the project in these two sub-districts. If project staff anticipated this by focusing resources in these two sub-districts the project might have been more intensive here. For these reasons it could be the case that the average cost per farmer in our sample is higher than the average cost per farmer reached by SAFAL.
} 
chains (see Section 3.3). To deal with this uncertainty I consider a yearly reduction of project benefits between $0 \%$ and $100 \%$. A yearly reduction rate of $0 \%$ means estimated effects recur yearly and in perpetuity. A yearly reduction rate of $100 \%$ means the project effects do not recur at all.

\begin{tabular}{|c|c|c|c|c|c|}
\hline & \multicolumn{5}{|c|}{ Expected yearly reduction rate of project benefits } \\
\hline & $0 \%$ & $25 \%$ & $50 \%$ & $75 \%$ & $100 \%$ \\
\hline $\begin{array}{l}\text { Net-present value of project } \\
\text { benefits (USD) }\end{array}$ & 3805,4 & 1245.3 & 735.0 & 521.3 & 403.9 \\
\hline Cost-benefit ratio & $1 / 15.1$ & $1 / 4.9$ & $1 / 2.9$ & $1 / 2.1$ & $1 / 1.6$ \\
\hline
\end{tabular}

The resulting net-present value of project benefits and the corresponding cost-benefit ratios are presented in Table 6 . The wide range of cost-benefit ratio's, from 1/15.1 to 1/1.6, suggest a high dependency on the extent to which the project effects are sustainable. It is also clear, from these results, that the project can be considered cost-effective even if the project effects do not recur at all. In this case the cost-benefit ratio is $1 / 1.6$, implying an increase of USD 1.6 in net-farm income for every US Dollar invested.

\section{Summary and concluding remarks}

Using a transaction costs framework, this paper defined value chain development as an intervention that intends to improve the functioning of a specific value chain by reducing the transaction costs between different stages and by supporting specific value chain actors. The paper also discussed the different policy options available to develop value chains, including facilitating multi-stakeholder platforms, assisting lead firms with the introduction of value chain innovations, or direct public support in the value chain in anticipation of downstream demand. 
The paper proceded with a detailed illustration of the latter approach by describing the publicly-funded VCD project "SAFAL" in South West Bangladesh. The general strategy of this project is to first identify a demand downstream in the value chain and then to assist the upstream part of the value chain to meet this demand by reducing transaction costs in the chain and assisting farmers and farm service providers through financial and technical support. One important way in which SAFAL intends to overcome the high transaction costs that would otherwise fall on the private actors is by organizing farmers and by representing them in coordination activities with agribusinesses. In addition, by supporting the emergence of small farmservice providers that take an intermediary role between the farmer and big agribusiness (i.e., agricultural technology companies, food processors, retailers), SAFAL reduces the costs for farmers to acquire farm inputs and services and to sell their produce to high-value markets.

Using a matched difference-in-difference methodology, the paper estimates this approach led to an increase in net-farm income of USD 404 and a reduction in the length of the hungry season by 12 days. There is no indication of high opportunity costs in terms of losses in wage or land rent income as a result of project participation. A cost-benefit analysis suggests that the project is cost-effective even if we assume the estimated effects were a one-off event and not recurring after the project ends. A broader implication of these findings is that high transaction costs indeed seem to constrain the transformation of value chains and that a selective intervention using public funds can play an important role in overcoming these costs.

There are, however, a number of limitations to the applied estimation strategy. First, although the matched difference-in-difference estimator allows for controlling for a large number of household characteristics, it cannot completely exogenize project participation. Secondly, spillover effects are minimized by sampling the control farmers from different unions than where the project is working, but are not otherwise controlled for and cannot be ruled out. 
Thirdly, there might be (unintentional) consequences that are not taken into account. The project might, for example, have led to substitution of project farmers for non-project farmers in certain high-value value chains. Other stakeholders that are likely to have been affected by the project but for which the effects are not assessed include the supported micro-entrepreneurs, the laborers in the value chains, and consumers. Neither does the data allow for an explicit assessment of the effect of SAFAL on value chain efficiency and value chain effectiveness. Finally, the study has not captured the longer term effects of the project. ${ }^{24}$ It is yet unclear, for example, whether the newly established institutional structures will continue to exist also after the project ends. This is considered an important risk for publicly-funded value chain development in general (Shanoyan et al. 2014).

This paper showed that investing public funds in integrated value chain development can be a cost-effective way to improve farmer welfare and food security. Obviously, this does not imply that value chain development will be effective as a policy instrument in any way it is implemented in any type of context. SAFAL is considered a particularly flexible, intensive, and integrated approach, also in comparison to other integrated VCD programs (see e.g., IOB 2017), and is implemented in a dynamic context with rapidly transforming aquaculture and horticulture value chains. More research is needed to get a better grasp at what type of public value chain intervention is most cost-effective in what context. In addition, future research could use better identification strategies, such as randomized controlled trials, and should look beyond the immediate short-term effects on farmers.

\footnotetext{
${ }^{24}$ In fact, the project was extended for a second phase (2017-2021).
} 


\section{References}

Abadie, Alberto. 2005. "Semiparametric Difference-in-Differences Estimators." The Review of Economic Studies 72 (1): 1-19.

Alene, Arega D., V. M. Manyong, G. Omanya, H. D. Mignouna, M. Bokanga, and G. Odhiambo. 2008. "Smallholder Market Participation under Transactions Costs: Maize Supply and Fertilizer Demand in Kenya." Food Policy 33 (4): 318-328.

Andersson, C.I., Chege, C.G., Rao, E.J., Qaim, M., 2015. Following up on smallholder farmers and supermarkets in Kenya. American Journal of Agricultural Economics 97, 1247-1266.

Ashraf, N., Giné, X., Karlan, D., 2009. Finding missing markets (and a disturbing epilogue): evidence from an export crop adoption and marketing intervention in Kenya. American Journal of Agricultural Economics 91, 973-990.Barrett, Christopher B. 2008. "Smallholder Market Participation: Concepts and Evidence from Eastern and Southern Africa." Food Policy 33 (4): 299 317. https://doi.org/10.1016/j.foodpol.2007.10.005.

Barrett, C., Reardon, T., Swinnen, J., Zilberman, D., 2019. Structural Transformation and Economic Development: Insights from the Agri-food Value Chain Revolution. Mimeo, Cornell University.

Bellemare, Marc F., and Jeffrey R. Bloem. 2018. "Does Contract Farming Improve Welfare? A Review." World Development 112 (December): 259-71. https://doi.org/10.1016/j.worlddev.2018.08.018.

Biggeri, M., Burchi, F., Ciani, F., Herrmann, R., 2018. Linking small-scale farmers to the durum wheat value chain in Ethiopia: Assessing the effects on production and wellbeing. Food policy 79, 77-91.

Bilinsky, Paula, and Anne Swindale. 2010. "Months of Adequate HouseholdFood Provisioning (MAHFP) ForMeasurement of Household Food Access: Indicator Guide (v. 4).” Washington, D.C.: FHI 360/FANTA.

Bold, Tessa, Kayuki C. Kaizzi, Jakob Svensson, and David Yanagizawa-Drott. 2017. "Lemon Technologies and Adoption: Measurement, Theory and Evidence from Agricultural Markets in Uganda." The Quarterly Journal of Economics 132 (3): 1055-1100. https://doi.org/10.1093/qje/qjx009.

Bryson, Alex, Richard Dorsett, and Susan Purdon. 2002. "The Use of Propensity Score Matching in the Evaluation of Active Labour Market Policies."

Caliendo, Marco, and Sabine Kopeinig. 2008. "Some Practical Guidance for the Implementation of Propensity Score Matching." Journal of Economic Surveys 22 (1): 31-72.

Carter, Michael R., Emilia Tjernström, and Patricia Toledo. 2019. "Heterogeneous Impact Dynamics of a Rural Business Development Program in Nicaragua." Journal of Development Economics 138 (May): 77-98. https://doi.org/10.1016/j.jdeveco.2018.11.006.

Cavatassi, Romina, Mario González-Flores, Paul Winters, Jorge Andrade-Piedra, Patricio Espinosa, and Graham Thiele. 2011. "Linking Smallholders to the New Agricultural Economy: The Case of the Plataformas de Concertación in Ecuador." Journal of Development Studies 47 (10): 1545-1573.

Chabé-Ferret, Sylvain. 2017. "Should We Combine Difference In Differences with Conditioning on Pre-Treatment Outcomes?" 17-824. TSE Working Paper. https://www.tse-fr.eu/publications/should-we-combine-difference-differences-conditioning-pre-treatment-outcomes.

Christiaensen, L., Vandercasteelen, J., 2019. Earning More on the Farm. In Accelerating Poverty Reduction in Africa, edited by Kathleen Beegle and Luc Christiaensen, 95 - 143. Washington D.C.: The World Bank.

Croppenstedt, Andre, Mulat Demeke, and Meloria M. Meschi. 2003. "Technology Adoption in the Presence of Constraints: The Case of Fertilizer Demand in Ethiopia." Review of Development Economics 7 (1): 58-70. 
Daw, Jamie R., and Laura A. Hatfield. 2018. "Matching and Regression to the Mean in Difference-inDifferences Analysis." Health Services Research 53 (6): 4138-56. https://doi.org/10.1111/1475-6773.12993.

De Janvry, Alain, Marcel Fafchamps, and Elisabeth Sadoulet. 1991. "Peasant Household Behaviour with Missing Markets: Some Paradoxes Explained.” The Economic Journal 101 (409): 14001417.

De Janvry, A., Sadoulet, E., 2020. Using agriculture for development: Supply- and demand-side approaches. World Development 133, 105003. https://doi.org/10.1016/j.worlddev.2020.105003

Dehejia, Rajeev H., and Sadek Wahba. 1999. "Causal Effects in Nonexperimental Studies: Reevaluating the Evaluation of Training Programs." Journal of the American Statistical Association 94 (448): 1053-1062.

Devaux, André, Douglas Horton, Claudio Velasco, Graham Thiele, Gastón López, Thomas Bernet, Iván Reinoso, and Miguel Ordinola. 2009. "Collective Action for Market Chain Innovation in the Andes." Food Policy 34 (1): 31-38.

Devaux, André, Maximo Torero, Jason Donovan, and Douglas E. Horton. 2016. Innovation for Inclusive Value-Chain Development: Successes and Challenges. Washington, D.C.: International Food Policy Research Institute (IFPRI).

Ebata, Ayako, and Silke Huettel. 2017. "The Effect of Value Chain Interventions for Staple Crops: Evidence from Small-Scale Farmers in Nicaragua." The Journal of Development Studies, 118.

Grashuis, J., Su, Y., 2019. A review of the empirical literature on farmer cooperatives: Performance, ownership and governance, finance, and member attitude. Annals of Public and Cooperative Economics 90, 77-102.

Headey, Derek D., and John Hoddinott. 2016. "Agriculture, Nutrition and the Green Revolution in Bangladesh.” Agricultural Systems 149 (November): 122-31. https://doi.org/10.1016/j.agsy.2016.09.001.

Heckman, James, Hidehiko Ichimura, Jeffrey Smith, and Petra Todd. 1998. "Characterizing Selection Bias Using Experimental Data.” Econometrica 66 (5): 1017-1098.

Heckman, James J., Hidehiko Ichimura, and Petra E. Todd. 1997. "Matching as an Econometric Evaluation Estimator: Evidence from Evaluating a Job Training Programme." The Review of Economic Studies 64 (4): 605-654.

Hernandez, Ricardo, Ben Belton, Thomas Reardon, Chaoran Hu, Xiaobo Zhang, and Akhter Ahmed. 2018. "The 'Quiet Revolution' in the Aquaculture Value Chain in Bangladesh." Aquaculture 493: 456-468.

Hirano, Keisuke, and Guido W. Imbens. 2001. "Estimation of Causal Effects Using Propensity Score Weighting: An Application to Data on Right Heart Catheterization." Health Services and Outcomes Research Methodology 2 (3-4): 259-278.

Hirano, Keisuke, Guido W. Imbens, and Geert Ridder. 2003. "Efficient Estimation of Average Treatment Effects Using the Estimated Propensity Score." Econometrica 71 (4): 1161-1189.

Hobbs, Jill E. 1997. "Measuring the Importance of Transaction Costs in Cattle Marketing." American Journal of Agricultural Economics 79 (4): 1083-1095.

Fischer, E., Qaim, M., 2012. Linking Smallholders to Markets: Determinants and Impacts of Farmer Collective Action in Kenya. World Development 40, 1255-1268. https://doi.org/10.1016/j.worlddev.2011.11.018

Jalil, M.M., 2010. Approaches to measuring social discount rate: A Bangladesh perspective. Available at SSRN 1921987.

Fuglie, K., Gautam, M., Goyal, A., Maloney, W.F., 2019. Harvesting Prosperity: Technology and Productivity Growth in Agriculture. The World Bank.

IOB. 2017. "Food for Thought. Review of the Dutch Food Security Policy 2012-2016." 419. Den Haag: IOB.

Kabunga, N.S., Dubois, T., Qaim, M., 2014. Impact of tissue culture banana technology on farm household income and food security in Kenya. Food policy 45, 25-34.

Kersting, Sarah, and Meike Wollni. 2012. "New Institutional Arrangements and Standard Adoption: Evidence from Small-Scale Fruit and Vegetable Farmers in Thailand." Food Policy 37 (4): $452-462$. 
Key, Nigel, Elisabeth Sadoulet, and Alain De Janvry. 2000. "Transactions Costs and Agricultural Household Supply Response.” American Journal of Agricultural Economics 82 (2): 245-259.

Kolavalli, S., Mensah-Bonsu, A., Zaman, S., 2015. Agricultural value chain development in practice: Private sector-led smallholder development.

Kuijpers, Rob, and Johan Swinnen. 2016. "Value Chains and Technology Transfer to Agriculture in Developing and Emerging Economies." American Journal of Agricultural Economics 98 (5): 1403-18. https://doi.org/10.1093/ajae/aaw069.

Maertens, M., Velde, K.V., 2017. Contract-farming in staple food chains: the case of rice in Benin. World Development 95, 73-87.

Maertens, Miet, Bart Minten, and Johan Swinnen. 2012. "Modern Food Supply Chains and Development: Evidence from Horticulture Export Sectors in Sub-Saharan Africa." Development Policy Review 30 (4): 473-497.

Mangnus, E., Van Westen, A.C.M., 2018. Roaming through the maze of maize in Northern Ghana. A systems approach to explore the long-term effects of a food security intervention. Sustainability 10,3605 .

Michelson, H.C., 2013. Small farmers, NGOs, and a Walmart world: welfare effects of supermarkets operating in Nicaragua. American Journal of Agricultural Economics 95, 628-649.

Negi, D.S., Birthal, P.S., Roy, D., Khan, Md.T., 2018. Farmers' choice of market channels and producer prices in India: Role of transportation and communication networks. Food Policy 81, 106-121. https://doi.org/10.1016/j.foodpol.2018.10.008

Pingali, Prabhu, Yasmeen Khwaja, and Madelon Meijer. 2005. "Commercializing Small Farms: Reducing Transaction Costs." The Future of Small Farms 61: 5-8.

Ragasa, C., Lambrecht, I., Kufoalor, D.S., 2018. Limitations of contract farming as a pro-poor strategy: the case of maize outgrower schemes in Upper West Ghana. World Development 102, 30-56.Reardon, Thomas, Christopher B. Barrett, Julio A. Berdegué, and Johan Swinnen. 2009. "Agrifood Industry Transformation and Small Farmers in Developing Countries." World Development 37 (11): 1717-27. https://doi.org/10.1016/j.worlddev.2008.08.023.

Reardon, T., Barrett, C.B., Berdegué, J.A., Swinnen, J., 2009. Agrifood Industry Transformation and Small Farmers in Developing Countries. World Development 37, 1717-1727. https://doi.org/10.1016/j.worlddev.2008.08.023

Rosenbaum, Paul R., and Donald B. Rubin. 1983. "The Central Role of the Propensity Score in Observational Studies for Causal Effects." Biometrika, 41-55.

Roy, Andrew Donald. 1951. "Some Thoughts on the Distribution of Earnings." Oxford Economic Papers 3 (2): 135-146.

Ruben, Ruerd. 2017. "Impact Assessment of Commodity Standards: Towards Inclusive Value Chains." Enterprise Development and Microfinance 28 (1-2): 82-97. https://doi.org/10.3362/1755-1986.16-00020.

Rubin, Donald B. 1974. "Estimating Causal Effects of Treatments in Randomized and Nonrandomized Studies." Journal of Educational Psychology 66 (5): 688.

Shanoyan, A., Brent Ross, R., Gow, H.R., Christopher Peterson, H., 2014. Long-term sustainability of third-party facilitated market linkages: Evidence from the USDA marketing assistance program in the Armenian dairy industry. Food Policy 46, 157-164. https://doi.org/10.1016/j.foodpol.2014.03.013

Shiferaw, Bekele, Kebede Tewodros, Kassie Menale, and Fisher Monica. 2015. "Market Imperfections, Access to Information and Technology Adoption in Uganda: Challenges of Overcoming Multiple Constraints." Agricultural Economics 46 (4): 475-88. https://doi.org/10.1111/agec.12175.

Smith, Jeffrey A., and Petra E. Todd. 2005. "Does Matching Overcome LaLonde's Critique of Nonexperimental Estimators?” Journal of Econometrics 125 (1-2): 305-353.

Solidaridad. 2017. Sustainable Agriculture, Food Security and Linkages (SAFAL). Project Completion Report. November 2012 to June 2017.

Splawa-Neyman, Jerzy, Dorota M. Dabrowska, and T. P. Speed. 1990. "On the Application of Probability Theory to Agricultural Experiments. Essay on Principles. Section 9." Statistical Science, 465-472. 
Sur, Mona, and Zaki Uz Zaman. 2008. "High-Value Agriculture in Bangladesh : As Assessment of Agro-Business Opportunities and Constraints." 45760. The World Bank. http://documents.worldbank.org/curated/en/640841467997275218/High-value-agriculture-in-Bangladesh-as-assessment-of-agro-business-opportunities-and-constraints.

Svensson, Jakob, and David Yanagizawa. 2009. "Getting Prices Right: The Impact of the Market Information Service in Uganda." Journal of the European Economic Association 7 (2-3): 43545. https://doi.org/10.1162/JEEA.2009.7.2-3.435.

Rao, E.J., Qaim, M., 2011. Supermarkets, farm household income, and poverty: insights from Kenya. World Development 39, 784-796.

Swinnen, Johan, and Rob Kuijpers. 2019. "Value Chain Innovations for Technology Transfer in Developing and Emerging Economies: Conceptual Issues, Typology, and Policy Implications." Food Policy 83 (February): 298-309. https://doi.org/10.1016/j.foodpol.2017.07.013.

Swinnen, J., Kuijpers, R., 2020. Inclusive Value Chains to Accelerate Poverty Reduction in Africa, Jobs Working Paper. World Bank.

Swinnen, J., 2007. Global Supply Chains, Standards and the Poor: How the Globalization of Food Systems and Standards Affects Rural Development and Poverty. CABI.

Ton, Giel, Wytse Vellema, Sam Desiere, Sophia Weituschat, and Marijke D'Haese. 2018. “Contract Farming for Improving Smallholder Incomes: What Can We Learn from Effectiveness Studies?" World Development 104: 46-64.

Townsend, R., Ronchi, L., Brett, C., Moses, G., 2018. Future of Food: Maximizing Finance for Development in Agricultural Value Chains. World Bank.

Villa, Juan. 2016. "Diff: Simplifying the Estimation of Difference-in-Differences Treatment Effects." Stata Journal 16 (1): 52-71.

Winter-Nelson, Alex, and Anna Temu. 2005. "Impacts of Prices and Transactions Costs on Input Usage in a Liberalizing Economy: Evidence from Tanzanian Coffee Growers." Agricultural Economics 33 (3): 243-53. https://doi.org/10.1111/j.1574-0864.2005.00064.x.

World Bank, 2005. The Dynamics of Vertical Coordination in Agrifood Chains in Eastern Europe and Central Asia: Implications for Policy and World Bank Operations. The World Bank, Washington, D.C. 